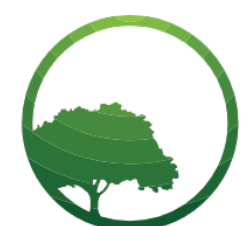

Business \& Social Science IJRBS

\section{Research in Business and Social Science}

IJRBS Vol 7 No 1, ISSN: 2147-4478

Contents available at www.ssbfnet.com/ojs https://doi.org/10.20525/ijrbs.v7i1.834

\title{
The Moderator Role of Brand Awareness and Brand Loyalty on Consumers' Online Impulse Buying Behavior
}

\section{Melis Kaytaz Yiğit}

Yigit Metal, Samsun, Turkey

\section{Mehmet Tığlı}

Business, Marmara University, Istanbul, Turkey

\begin{abstract}
In recent years, with consumers' widespread preference for shopping in Private Shopping Clubs (PSCs) on the internet, there has been a remarkable increase in impulse purchases with the attractive opportunities and smart strategies of PSCs stimulating consumers' impulse buying behavior. Within the PSC framework, the purpose of this article is to investigate the moderator effect of brand awareness and brand loyalty on the relationship between online impulse buying behavior and perceived low price, browsing behavior and time pressure. The study created and tested five hypotheses using data collected in Turkey. Results indicate that browsing behavior, time pressure and perceived low price do influence online impulse buying behavior. A hierarchical regression analysis was also used to analyze the moderating role of brand awareness and brand loyalty on impulse buying behavior and both variables were found to have a moderating role. The results provide substantial information on strategy development for internet retailers.
\end{abstract}

Key words: Online Impulse Buying, Brand Awareness, Brand Loyalty, Impulsiveness, Private Shopping Clubs

JEL classification: M30

\section{Introduction}

Impulse buying has always been a key consumer behavior, and it has a unique buying behavior structure. Based on the different descriptions in the literature, this study defined impulsive buying behavior as "consumers making an instant purchase decision without planning it beforehand due to a drive or stimulant." Today, retailers encourage consumers to make impulse purchases, taking advantage of a number of newly developed strategies. Different practices including shelf arrangements, product packages and in-shop 
promotions are some of the most important factors that direct consumers to make impulse purchases. Innovations and technological developments have made it easier for consumers to make impulse purchases and studies have shown that these are a significant percentage of annual sales (Hausman, 2000). Innovations in internet technology form the largest share of these developments and they have altered consumers' buying behaviors. As the use of the internet has grown both geographically and technically, the rates of online purchases have increased remarkably. Now, individuals are able to connect to the internet whenever they want and internet retailers are always open, which are two of the factors that increase these rates. Buying on the internet enables consumers to shop at any moment without any difficulties or effort. For this reason, it has been suggested that people who shop online are more impulsive than those who shop in conventional ways (Donthu and Garcia, 1999).

In recent years, there has been a growing preference among consumers to use Private Shopping Clubs (PSCs) in their online purchases. PSCs offer the products of distinct brands in a limited timeframe and from a limited stock with low prices. When consumers desire to purchase the limited numbers of these products on these websites, they must buy them in a specific period of promotion.

If online buying behaviors are examined in a detailed way, this will help internet marketers to use more conscious and strategic approaches in their sales activities. A majority of the studies of online impulse purchases in the literature have examined this behavior in the framework of the basic characteristics of the internet environment, including the features or the atmosphere of the website, and do not mention the effects of product-related, personal or situational characteristics on buying behavior. This study will analyze the structure of consumers' impulse buying behaviors during their purchases from PSCs on the internet. The objective of the study is to determine the effect on buying behavior from PSCs of a number of factors, including time pressure, perceived low price and browsing behavior, and to determine the moderator effects of brand awareness and brand loyalty and online impulse buying behavior.

The analyses created by the statistical research will provide new and important information to businesses in this field and to marketers and the academics who study this subject. It will also will make it easier to understand the stereotypical buying behaviors of consumers who make impulse purchases.

\section{Literature Review}

\section{Impulse Buying Behavior}

A majority of early studies conducted on impulse buying behavior focused on the description and categorization of this concept and many authors (Cobb and Hoyer, 1986; Rook, 1987; Rook and Fisher, 1995) claimed that impulse purchases were based on low prices. Later, more large-scale studies, found that impulse buying was a behavior that was founded in the personalities of the consumers rather than a reaction to discount offers (Hausman, 2000).

In the earliest studies, "impulse buying" was synonymous with unplanned buying, and most of these studies focused on the interests of administration in businesses. Later, the concept of impulse buying was modified to include unplanned shopping and exposure to a stimulant. Applebaum (1951) was the first to claim that impulse buying behavior was created by an impulse that was formed using a sale promotion instrument in the shop. In later years, D'Antoni and Shenson (1973) thought that it was not sufficient that the only criteria for impulse buying were that it be unplanned and in a physical shop, and stressed that this concept should also include "rapidity."

From 1982, researchers began to refocus on impulse buying behavior and this led to studying its behavioral components. Later studies (Cobb and Hoyer, 1986; Piron, 1991; Rook, 1987; Rook and Fisher, 1995), drew the conclusion that the concept of impulse buying included hedonic or emotional components (Hausman, 2000). Rook (1987) combined psychological components with impulse buying behavior and formed a new description of the impulse buying concept:

"When a consumer experiences a sudden, often powerful and persistent urge to buy something immediately. The impulse to buy is hedonically complex and may stimulate emotional conflict. Also impulse buying is prone to occur with diminished regard for its consequences" (Rook, 1987:191). 
A study by Prion in 1991 put forward the idea that impulse buying behavior consisted of four components which were being unplanned, being created by exposure to an impulse, being on the spot, and including emotional and cognitive reactions. For Prion, impulse buying behavior was an unplanned purchase which was decided at that moment and created by exposure to an impulse, and that the consumer had emotional and/or cognitive reactions after this purchase.

Beatty and Ferrell (1998) further developed Rook's description of impulse buying:

"Impulse buying is a sudden and immediate purchase with no pre-shopping intentions either to buy the specific product category or to fulfill a specific buying task. The behavior occurs after experiencing an urge to buy and it tends to be spontaneous and without a lot of reflection (i.e., it is "impulsive"). It does not include the purchase of a simple reminder item, which is an item that is simply out-of-stock at home" (Beatty and Ferrell, 1998;170).

Today, the internet is accepted as a shopping channel, and this led to many studies being conducted about impulse purchase and the internet also began to focus on this subject due to these studies. The rapid growth of online shopping has supported impulse buying, and this buying behavior is widespread in online shopping.

Those who shop on the internet are more impulsive, look for more diversity, take more risks and have less consciousness about brands and prices compared to those who do not shop on the internet (Donthu and Garcia, 1999). When compared to conventional shopping, online shopping provides consumers a wider range of products, offers them supporting information about the products and helps consumers spend less time accessing retailers and products, all of which increases the ease and utility of shopping (Madhavaram and Laverie, 2004). Past studies showed that there is a positive relationship between the ease of buying and impulse buying (Stern, 1962), and proved that browsing behavior also increased impulse buying (Beatty and Ferrell, 1998). In online shopping where individuals behave more spontaneously, online marketing easily drives consumption to be impulsive, and makes online consumers less risk averse (Donthu and Garcia, 1999; Madhavaram and Laverie, 2004). Based on this, online shopping is more unplanned compared to conventional shopping.

\section{$\underline{\text { Time Pressure }}$}

Time pressure, which is the opposite of time convenience, is one of the exterior factors affecting consumer behaviors. Time pressure was determined as an exterior variable in the Theory of Buyer Behavior by Howard and Sheth (1969), and it was found that it had a great effect on consumption (Barbara and Gross, 1994).

According to Denton (1994), time pressure was a type of stress expression in a person's perception of hurry. In the framework of shopping, time pressure is mainly seen as shopping stress (Priour et al., 2012). Iyer (1989) described time pressure as an individual's perception of the convenience of the time for a specific task as limited.

In consumer behaviors, the concept of time pressure is studied in relation to its effect on the decision-making process and the knowledge-gaining process. The concept of time affects how knowledge is processed. Bettman (1979) stated that time convenience has a positive effect on knowledge-gaining process. Fried (1982) put forward the idea that there was a strong negative relationship between problem-solving performance and time pressure, which is just the opposite of time convenience. Bruner et al. (1956) mentioned that individuals are less-informed in decisions which are made under time pressure, and Jacoby et al. (1976) found that there was a positive relationship between time pressure and exposure to selective information (Barbara and Gross, 1994).

Swain et al. examined the influence of time pressure on consumers' buying intentions. This study concluded that time pressure created a sudden desire to purchase, and so it affected the intention to buy. Iyer (1989) also conducted a study with the objective of examining the influence of time pressure on unplanned buying. This study concluded that the buyers who felt a strong time pressure were inclined to buy fewer products than they had intended, and they also made less unplanned purchases (lyer, 1989).

On the other hand, the importance of time pressure in online shopping compared to conventional shopping has only recently featured in the literature. Nelmapius, Boshoff, Calitz and Klemz (2004) showed that time 


\section{K. Yiğit \& Tiğgl / International Journal of Research in Business and Social Science,}

Vol 7 No 1, 2018 ISSN: 2147-4486

pressure and the consumers' level of interest had a positively significant effect with regard to online buying behavior in the online shopping setting (Nelmapius et al., 2004).

Several web sites use the time pressure strategy to induce people make a buying decision spontaneously (Spears, 2001). Whittler (1994) stated that time limitation directed consumers to buy products with the fear of an increase in prices or running out of the stock. The time pressure strategy is used as a marketing instrument by retailers with the aim of activating consumers' intuition. In this type of cases, the consumer stops comparing the products and decides to immediately buy the product with less stock (Gierl et al., 2008). The PSCs also use a similar strategy. The web sites not only offer the brand products to consumers in a limited timeframe, but they also give them a limited time to purchase the products in their basket.

Based on this information;

$\mathrm{H} 1$ : There is a positively significant relationship between time pressure and online impulse buying behavior.

\section{Perceived Low Price}

Price is an important variable that affects consumers' different behaviors along with their attitude, satisfaction and buying intention. Consumers are usually prepared to pay the minimum price for their needs to be satisfied with a specific product. The most important point of the pricing strategy is to determine the market's view of the worth of a product (Blythe, 1997). Price perception is a comparative process which includes different times or parties (Dodds et al., 1991).

When consumers plan to shop online, they consider whether there is an important difference between conventional shopping and online shopping that matters to them. If they decide that the difference is insignificant, they are inclined to put both retailing channels in the same category. However, if they decide that the difference is significant, they perceive the two channels as different and their buying decision is changed (Lii and Lee, 2005). For consumers, the most fundamental difference between the two channels is the price of the product. In other words, consumers who shop online consider price more than the other factors in their buying decisions (Jensen et al., 2003).

A number of studies in the literature (Bellenger et al., 1978; Prion, 1991; McGoldrick et al., 1999; Dittmar and Drury, 2000; Crawford and Melewar, 2003; Zhou and Wong, 2003) found that price was an element that affected impulse buying behavior. Price is one factor related to a product, and it encourages impulse buying particularly when it is low (Stern, 1962).

Based on this information;

$\mathrm{H} 2$ : There is a positively significant relationship between perceived low price and online impulse buying behavior.

\section{Browsing Behavior}

Browsing is a type of search which is conducted before purchasing, and it is related to other searching behavior types. In its most general and widespread sense, browsing is described as analyzing shop visuals with the purpose of gaining information or just for fun (Bloch and Richinse, 1983). As indicated by its description, browsing is both an entertainment and a type of exterior searching behavior. By browsing, people can both satisfy their curiosity and feel that they enhance their self-respect by this product and shopping experience (Bloch and Richinse, 1983).

Kim (2003) determined that the impulse buying process started with browsing behavior. An individual displays browsing behavior with no intention to purchase, and has a sudden feeling of impulse buying as he or she continues browsing (Tinne, 2010). Rook (1987) and Bellenger et al. (1978) were two of the first authors to analyze the relationship between browsing behavior and impulse buying. Bellenger et al. (1978) said that browsing would lead to impulse unplanned purchases. Similarly, Rook (1987) claimed that consumers felt a sudden desire to buy products when they browse the visuals in a shop website.

In 1987, Jarboe and McDaniel put forward the idea that the consumers who browsed in conventional shops made more unplanned purchases compared to the consumers who did not browse. lyer (1989) claimed that there was a positive relationship between the number of the products purchased impulsively and the time 
spent on browsing. Beaty and Ferrell (1998) examined the effect of in-shop browsing behavior on the impulsive desire to buy. They proved that a positive emotional state influenced the browsing behavior; the more a person displayed browsing behavior, the more he or she had an impulsive desire to buy. In addition, the people who had fun when shopping and did not have any time limitations displayed more browsing behaviors (Beaty and Ferrell, 1998).

In later studies, Kim and Eastin (2001) looked at the relationship between impulsive buying behavior and browsing behavior in the framework of online shopping and found that the hedonic drive for shopping was the most fundamental element of exploratory information seeking and impulsive purchasing behavior. However, it was asserted that online buying behavior which was affected by a hedonic shopping drive influenced pre-purchase browsing time, and there was a positive relationship between pre-purchase browsing time and online buying frequency (Kim and Eastin, 2001).

Based on this information;

H3: There is a positively significant relationship between browsing behavior and online impulse buying.

\section{Brand Awareness}

Aaker (1996) stated that brand awareness was the strength of a brand's existence in the minds of consumers, and it was one of the four brand components to create and maintain brand equity. Similarly, Keller (2003) said that brand awareness was one of the components of brand equity and stated that it was a priority to create brand awareness to be able to form the Customer-based Brand Value model that he developed.

As it is the first stage of consumers' brand preference behavior, brand awareness plays a major role in buying behavior. With obvious brand awareness, the other processes will follow it (Heding et al., 2009). According to Keller (2003), consumers only buy products that are clearly understood and that they are familiar with. In the set of preferences, if there are any brands that meet the criteria determined by the consumers, they will prefer the brand they are aware of, without any need to gain information about the other brands. If there are multiple brands in the set of preferences, the strength of brand awareness will be the determinant (Macdonald and Sharp, 2000).

In the literature, there are no studies which examine the moderator role of brand awareness in the relationship between impulse buying behavior online or conventional shopping channels and the determinants of this behavior. Consumers are inclined to buy products with which they are familiar and know well and brand awareness has a great influence on consumers' buying decisions (Keller, 1993).

Biswas (1992) showed that brand awareness had a strong influence on consumers' price perception. On the other hand, browsing is a very rapid behavior which is displayed without thinking. If consumers see a brand they know when browsing in PSCs, they start to focus on the products of that brand. Since brand awareness has a major effect on the intention to buy (Keller, 2003), it has a positive effect on consumers' impulse purchases from PSCs. When consumers are in PSCs, this facilitates impulse purchase decisions without thinking about them.

Brand awareness also influences the time pressure created by the PSCs and the consumers' perception that the products in these websites are limited in number. Consumers do not need to think much about the brands they know, therefore, they make quicker decisions and impulse purchases to overcome the time pressure in PSCs. The impulse purchase desire for a well-known brand, though, is much higher. When consumers have a perception about the brand they know, of which there are a limited number of products, it causes them to make quicker and more sudden decisions and make impulse purchases.

Based on this information;

H4: Brand awareness plays a moderator role in the relationship between perceived low price, browsing behavior and time pressure and online impulse buying behavior.

\section{Brand Loyalty}

According to the description by Oliver (1999), brand loyalty is showing a purchasing commitment to a specific product, brand or brand group in the future, despite marketing efforts spent by competitors to induce 
consumers to change the brand they purchase. Oliver (1999) said that actual brand loyalty is a function of the perception of brand superiority, personal courage and social commitment, as well as a synergy of all of these (Taylor et al., 2004).

Baldinger and Rubinson (1996) said that the concept of loyalty should be studied in attitudinal and behavioral terms. Behavioral loyalty is explained as a repetitive buying behavior. In this approach, brand loyalty is the inclination to select and buy a single brand consistently among a number of brands in the same product group. Attitudinal brand loyalty is a person's positive attitude towards a specific brand and it includes a psychological commitment based on emotions and relationship (Kabiraj and Shanmugan, 2011).

In the literature, there are no studies examining the relationship between brand loyalty and impulse purchase or online impulse purchase. There are no studies of brand loyalty's moderator role in the relationship between impulse buying behavior and the factors affecting this behavior, either.

People who have a strong brand loyalty have little sensitivity to the price of the product. They are ready to pay high prices for the brands they are loyal to. Krishnamurthi and Raj (1991) proved that the people with strong brand loyalty have less sensitivity to price compared to those with low brand loyalty.

However, consumers are inclined to browse the products of the brands they are loyal to more than other brands in PSCs. A more intense browsing behavior facilitates the purchases. Therefore, brand loyalty strengthens the relationship between these two behaviors.

The time pressure felt in the PSCs and consumers' perception that the products in these websites are limited in number are also influenced by brand loyalty. Consumers want to buy the products of the brands they are familiar with more quickly than the products of other brands. The time pressure in these websites provokes this desire, and may cause impulse purchase. When a brand the consumer is loyal to is offered in PSCs and the number of the products is limited, consumers perceive this situation as a stimulant. The desire to have the limited product of a brand they are loyal to facilitates the impulse purchase by the consumers.

Based on this information;

H5: Brand loyalty plays a positive moderator role in the relationship between perceived low price, browsing behavior and time pressure, and online impulse purchasing behavior.

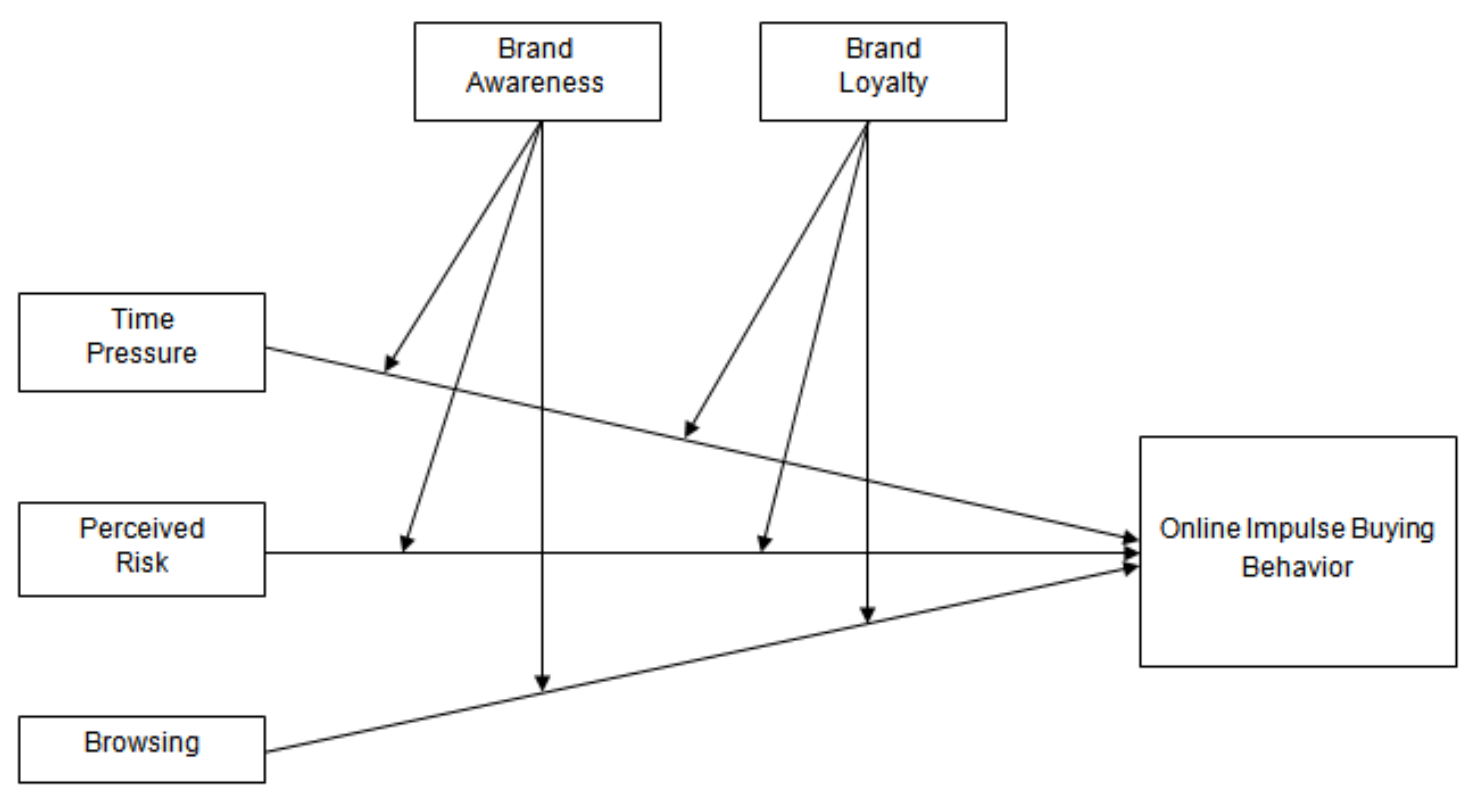

Figure 1: Conceptual model of the study. 


\section{Research and Methodology}

\section{Procedure and Study Sample}

The study used a quantitative methodology employing a self-administered structured questionnaire to measure and validate the hypothesized relationships. This study investigates consumers' online impulse buying behavior in Private Shopping Clubs (PSCs). The reason for focusing on PSCs is the increase in the buying rate in shopping in PSCs and the strategies that PSCs use to encourage consumers to make impulse purchases. Data was collected from a convenience sample in two Turkish cities, Samsun and İstanbul. Tabachnich and Fiddel (2007) suggest that the sample size of study should be calculated taking the number of dependent variables into consideration $(\mathrm{N}>50+8 \mathrm{~m})$. A usable sample of 515 surveys was received from face-to-face surveys and online surveys with a response rate of $93 \%$.

\section{Measures and Scale Reliabilities}

All items were measured using a 5-point Likert scale, which ranged from 1 (strongly disagree) to 5 (strongly agree). The online impulse buying was measured with nine items, such as "I often buy things spontaneously" and adopted from Rook and Fisher (1995). The browsing was measured with three items, including "The percent of time I spent just looking around on the Private Shopping Clubs was fairly high" and adopted from Beatty and Ferrel (1998). The time pressure scale was adopted from Herrington and Capella (1995). The scale measured three items, including "I must hurry if I am to complete my shopping trip on time in Private Shopping Club." The perception of low price was measured with four items, including "The products are reasonably priced in Private Shopping Club," and adopted from Byun and Sternquist (2008). The brand awareness scale was adopted from Kent and Allen (1994) and was measured with three items, including "I am familiar with the brand which I buy impulsively". Brand loyalty was measured with three items, including "I will continue to use this brand because I am satisfied and acquainted with the brand" adopted from Kim (1998).

Cronbach's alpha $(\alpha)$ coefficient was used to calculate the reliability of each factor in the questionnaire. The alpha of each factor was as follows: "online impulse buying behavior2 $(\alpha=0.849)$, "browsing" $(\alpha=0,628)$, "time pressure" ( $\alpha=0,824)$, "perceived low price" ( $\alpha=0,733)$, "brand awareness" $(\alpha=0,781)$ and "brand loyalty" ( $\alpha=0,718)$. Cronbach's alpha values greater than 0,6 (Hair et al., 1998) and 0.7 (Nunally, 1978) are considered reliable. Each factor was measured using Cronbach's alpha value to ensure reliability.

\section{Analysis and Findings}

\section{The demographic characteristics of sample}

Of the 515 respondents $72.8 \%$ were female, $27 \%$ were male and the highest percentage of respondents (40\%) belonged to the 26 to 35 years age group. More than half of them were married $(56.1 \%)$ and $46.8 \%$ had high school education. Table 1 shows the demographic characteristics of the respondents. 
K. Yiğit \& Tiğlı / International Journal of Research in Business and Social Science,

Vol 7 No 1, 2018 ISSN: 2147-4486

Table 1: Sample demographics

\begin{tabular}{|l|l|l|l|l|l|}
\hline Demographic variables & Frequency & $\%$ & Demographic variables & Frequency & $\%$ \\
\hline Gender & & & Income level & & \\
\hline Male & 140 & 27.2 & Under 500 TRY & 10 & 1.9 \\
\hline Female & 375 & 72.8 & 500 TRY-1.000 TRY & 15 & 2.9 \\
\hline Age (years) & & & 1.000 TRY-3.000 TRY & 270 & 52.4 \\
\hline Younger than 18 & 27 & 5.2 & 3.000 TRY-5.000 TRY & 164 & 31.8 \\
\hline $19-25$ & 147 & 28.5 & Above 5.000 TRY & 56 & 10.9 \\
\hline $26-35$ & 207 & 40.2 & Occupation & & \\
\hline $36-40$ & 58 & 11.3 & Student & 41 & 8.0 \\
\hline $41-50$ & 68 & 13.2 & Private sector & 262 & 50.9 \\
\hline $51-60$ & 8 & 1.6 & Public sector & 73 & 14.2 \\
\hline Marital status & & & Self-employed & 102 & 19.8 \\
\hline Single & 226 & 43.9 & Housewife & 24 & 4.7 \\
\hline Married & 289 & 56.1 & Retired & 7 & 1.4 \\
\hline Education Level & & & Unemployed & 6 & 1.2 \\
\hline Primary school & 17 & 3.3 & & & \\
\hline Secondary school & 23 & 4.5 & & & \\
\hline High school & 241 & 46.8 & & & \\
\hline Associate's degree & 35 & 6.8 & & & \\
\hline Bachelor's degree & 168 & 32.6 & & & \\
\hline Master's degree & 24 & 4.7 & & & \\
\hline Doctoral degree & 7 & 1.4 & & & \\
\hline
\end{tabular}

\section{Analysis of direct effects on impulse buying behavior}

The direct effects of browsing, perceived low price and time pressure on online impulse buying behavior were analyzed by using correlation and regression analysis. The correlation analysis results presented in Table 2 support the hypothesis that time pressure $(r=0.218)$, perceived low price $(r=0.310)$ and browsing $(r=0.311)$ have a significant positive relationship with online impulse buying behavior.

Table 2: Correlation analysis result

\begin{tabular}{lllll}
\hline Variables & 1 & 2 & 3 & 4 \\
\hline 1. Browsing & 1.00 & 0.280 & 0.096 & 0.311 \\
2. Perceived Low Price & 0.280 & 1.00 & 0.110 & 0.310 \\
3. Time Pressure & 0.960 & 0.110 & 1.00 & 0.218 \\
4. Online Impulse Buying Behavior & 0.311 & 0.310 & 0.218 & 1.00 \\
\hline
\end{tabular}

Then multiple regression analysis was used to test $\mathrm{H}_{1}, \mathrm{H}_{2}$ and $\mathrm{H}_{3}$. As shown by the Table 3 , the F-value of the model is 37.193 with the significance of 0.000 which reveals that the proposed model is statistically significant. $\mathrm{H}_{1}$ predicted a positive relationship between perceived low price and online impulse buying behavior. The result of the analyses indicated that there is a significantly positive relationship between perceived low price $(b=0.226, p<0.00)$ and online impulse buying behavior, providing support to $H_{1}$. In support of $\mathrm{H}_{2}$, time pressure was found to have a statistically significant positive impact $(b=0.171, p<0.000)$ on online impulse buying behavior. $\mathrm{H}_{3}$ predicts that browsing behavior has significantly positive effect on online impulse buying behavior. The results show that there is a significantly positive relationship between browsing $(b=0.231 p<0.00)$ and online impulse buying behavior. 
K. Yiğit \& Tiğglı / International Journal of Research in Business and Social Science,

Vol 7 No 1, 2018 ISSN: 2147-4486

Table 3: Regression analysis results

\begin{tabular}{|c|c|c|c|c|c|c|c|c|c|}
\hline & Beta & $t$ & $p$ & Tolerance & VIF & $F$ & $p$ & $R$ & $R^{2}$ \\
\hline Model & & & & & & 37.197 & 0.00 & 0.423 & 0.179 \\
\hline (Constant) & & 0.924 & 0.356 & & & & & & \\
\hline Browsing & 0.231 & 5.520 & 0.00 & 0.917 & 1.09 & & & & \\
\hline $\begin{array}{l}\text { Time } \\
\text { Pressure }\end{array}$ & 0.171 & 4.236 & 0.00 & 0.983 & 1.017 & & & & \\
\hline $\begin{array}{l}\text { Perceived } \\
\text { Low Price }\end{array}$ & 0.226 & 5.397 & 0.00 & 0.914 & 1.094 & & & & \\
\hline
\end{tabular}

\section{The moderating effects of brand awareness and brand loyalty}

Hierarchical regression analyses were used to assess the moderating affects of brand loyalty and brand awareness on the relationship between the proposed models. $\mathrm{H}_{4}$ predicted that brand awareness has a significantly positive moderating effect on the relationship between browsing, perceived low price, time pressure and online impulse buying behavior. The results of the moderating effect of brand awareness are shown in the Table 4. The $F$ value of Model 4 was found to be 29.415 with the significance of 0.000 which reveals that the proposed model is statistically significant. As predicted in $\mathrm{H}_{4}$, brand awareness was found to have a significantly weak positive $(b=0.09 p<0.023)$ moderating effect on the relationship between online impulse buying behavior and the proposed variables.

Table 4: Summary of hierarchical regression analysis of brand awareness

\begin{tabular}{|c|c|c|c|c|c|c|c|c|c|c|c|}
\hline & Beta & $\mathbf{t}$ & $p$ & Tolerance & VIF & $\mathbf{F}$ & $p$ & $\Delta \mathbf{F}$ & $p$ & $R^{2}$ & $\Delta R^{2}$ \\
\hline Model 1 & & & & & & 54.883 & 0.00 & 54.883 & 0.00 & 0.097 & 0.097 \\
\hline (Constant) & & 8.114 & 0.000 & & & & & & & & \\
\hline Browsing & 0.311 & 7.405 & 0.000 & 1.000 & 1.000 & & & & & & \\
\hline Model 2 & & & & & & 45.319 & 0.00 & 32.443 & 0.00 & 0.15 & 0.054 \\
\hline (Constant) & & 1.982 & 0.048 & & & & & & & & \\
\hline Browsing & 0.243 & 5.726 & 0.000 & 0.921 & 1.085 & & & & & & \\
\hline Perceived Low Price & 0.242 & 5.696 & 0.000 & 0.921 & 1.085 & & & & & & \\
\hline Model 3 & & & & & & 37.193 & 0.00 & 17.941 & 0.00 & 0.179 & 0.029 \\
\hline (Constant) & & 0.924 & 0.356 & & & & & & & & \\
\hline Browsing & 0.231 & 5.520 & 0.000 & 0.917 & 1.090 & & & & & & \\
\hline Perceived Low Price & 0.226 & 5.397 & 0.000 & 0.914 & 1.094 & & & & & & \\
\hline Time Pressure & 0.171 & 4.236 & 0.000 & 0.983 & 1.017 & & & & & & \\
\hline Model 4 & & & & & & 29.415 & 0.00 & 5.171 & 0.023 & 0.187 & 0.008 \\
\hline (Constant) & & 0.103 & 0.918 & & & & & & & & \\
\hline Browsing & 0.213 & 5.005 & 0.000 & 0.884 & 1.132 & & & & & & \\
\hline Perceived Low Price & 0.196 & 4.474 & 0.000 & 0.830 & 1.204 & & & & & & \\
\hline Time Pressure & 0.174 & 4.327 & 0.000 & 0.982 & 1.018 & & & & & & \\
\hline Brand Awareness & 0.099 & 2.274 & 0.023 & 0.842 & 1.187 & & & & & & \\
\hline \multicolumn{12}{|c|}{ Dependent Variable: Online Impulse Buying Behavior } \\
\hline
\end{tabular}

Peer-reviewed Academic Journal published by SSBFNET with respect to copyright holders. 
Hierarchical regression analyses were used once again to test the moderating effect of brand loyalty on the relationship between browsing, perceived low price, time pressure and online impulse buying behavior. As shown by the Table 5, the $F$ value of Model 4 was found to be 33.213 with the significance of 0.000 which reveals that the proposed model is statistically significant. As predicted in $\mathrm{H}_{5}$, brand loyalty was found to have a significantly positive $(b=0.179 p<0.000)$ moderating effect on the relationship between online impulse buying behavior and proposed variables. Thus, $\mathrm{H}_{5}$ was supported.

Table 5: Summary of hierarchical regression analysis of brand loyalty

\begin{tabular}{|c|c|c|c|c|c|c|c|c|c|c|c|}
\hline & Beta & $t$ & $p$ & Tolerance & VIF & $\mathbf{F}$ & $p$ & $\Delta \mathbf{F}$ & $p$ & $R^{2}$ & $\Delta R^{2}$ \\
\hline Model 1 & & & & & & 54.883 & 0.00 & 54.883 & 0.00 & 0.097 & 0.097 \\
\hline (Constant) & & 8.114 & 0.00 & & & & & & & & \\
\hline Browsing & 0.311 & 7.405 & 0.00 & 1 & 1 & & & & & & \\
\hline Model 2 & & & & & & 45.319 & 0.00 & 32.443 & 0.00 & 0.150 & 0.054 \\
\hline (Constant) & & 1.982 & 0.00 & & & & & & & & \\
\hline Browsing & 0.243 & 5.726 & 0.00 & 0.921 & 1.085 & & & & & & \\
\hline $\begin{array}{l}\text { Perceived } \\
\text { Low Price }\end{array}$ & 0.242 & 5.696 & 0.00 & 0.921 & 1.085 & & & & & & \\
\hline Model 3 & & & & & & 37.193 & 0.00 & 17.941 & 0.00 & 0.179 & 0.029 \\
\hline (Constant) & & 0.924 & 0.00 & & & & & & & & \\
\hline Browsing & 0.231 & 5.520 & 0.00 & 0.917 & 1.090 & & & & & & \\
\hline $\begin{array}{l}\text { Perceived } \\
\text { Low Price }\end{array}$ & 0.226 & 5.397 & 0.00 & 0.914 & 1.094 & & & & & & \\
\hline $\begin{array}{l}\text { Time } \\
\text { Pressure }\end{array}$ & 0.171 & 4.236 & 0.00 & 0.983 & 1.017 & & & & & & \\
\hline Model 4 & & & & & & 33.213 & 0.00 & 17.642 & 0.00 & 0.207 & 0.027 \\
\hline (Constant) & & $\begin{array}{l}- \\
0.618\end{array}$ & 0.537 & & & & & & & & \\
\hline Browsing & 0.212 & 5.116 & 0.00 & 0.908 & 1.103 & & & & & & \\
\hline $\begin{array}{l}\text { Perceived } \\
\text { Low Price }\end{array}$ & 0.166 & 3.801 & 0.00 & 0.816 & 1.226 & & & & & & \\
\hline $\begin{array}{l}\text { Time } \\
\text { Pressure }\end{array}$ & 0.174 & 4.327 & 0.00 & 0.983 & 1.017 & & & & & & \\
\hline $\begin{array}{l}\text { Brand } \\
\text { Loyalty }\end{array}$ & 0.179 & 2.274 & 0.00 & 0.857 & 1.167 & & & & & & \\
\hline
\end{tabular}

\section{Conclusion}

The purposes of this study were to examine the direct effect of browsing, perceived low price and time pressure on online impulse buying behavior, and to reveal the moderating role of brand awareness and brand loyalty on the relationship between proposed variables. The results clearly show that consumers' browsing behavior in Private Shopping Clubs (PSCs) has a direct effect on their impulse purchases. This result is consistent with research (Kim, 2003, Rook, 1987; Bellenger, 1978; Jarboe and McDaniel, 1987; lyer, 1989; Beaty and Ferrell,1998; Kim and Eastin, 2001; Bucklin and Sismerio, 2003; Kumar and Tomkins, 2009) that suggests browsing behavior positively influences impulse buying behavior. In addition to that positive impact of browsing on online impulse buying behavior, it confirms the results of Kim and Eastin (2011) who report similar findings in relation to browsing.

In examining the role of time pressure on online impulse buying behavior, it was found that time pressure directly affects online impulse buying behavior which means the strategies that PSCs use to make consumers feel time pressure is successful. In the literature, there are a significant number of studies that support this 
finding. Swain et al., (2006), Beatty and Ferrel (1998) and Lin and Chen (2011) point to the relationship between time pressure and impulse buying behavior. Nelmapius et al., (2004) and Lee et al., (2009) also support the idea that time pressure directly affects consumers' online buying behavior. In PSCs the branded products are offered for sale for a given period and they give consumers a short time to buy the product in their basket, which influences peoples' intentions to buy. The study findings show that this time pressure strategy affects consumers' online impulse purchase behaviors.

The results of analysis show the moderating role of brand awareness on the relationship between time pressure, browsing and perceived low price and online impulse buying behavior. An increase in a person's rate of remembering and recognizing also increases their information about the price of that brand's product, which strengthens the effect of the person's low price perception on online impulse purchase. However, it was found that an increase in the brand's level of recognition also increased the effect of online browsing behavior on online impulse purchase. In PSCs, people are more inclined to browse the brands they are aware of than the other brands. An increase in this awareness level also strengthens people's impulse purchase following the browsing behavior. Moreover, the study also proved that the effect of time pressure on online impulse purchase got stronger as the brand's level of recognition increased. When people see a brand they are aware of at a PSC, it causes them to want to have a closer look at the products of that brand. Particularly, an increase in the level of awareness of the brand in question further strengthens this desire. This desire enhances the sense of time pressure in PSCs and it affects the impulse purchases people make. In other words, the effect of time pressure on impulse purchases gets stronger as the level of awareness of the brand increases.

This study is unique as there are no other studies in the literature on the moderator role of a brand's level of recognition in the relationship between the elements mentioned above and online impulse purchases. In addition, the study makes an important contribution to the literature as it has shown that a brand's level of recognition plays a moderator role in the relationship between browsing, time pressure and online impulse purchase.

In examining the role of brand loyalty on the relationship between time pressure, browsing and perceived low price and online impulse buying behavior, it was found that brand loyalty has a significantly positive moderating role on the proposed relationship. This means that the effect of perceived low price on online impulse purchase increases as brand loyalty increases. Consumers are relatively better informed about the prices of the products of the brands they are loyal to. It especially strengthens their desire for impulse purchases when they see that the products of this brand are offered at lower prices and they immediately wish to own the brand to which they are loyal. The greater the loyalty to a brand, the more their perception of low prices about the products of that brand affects a consumer's purchasing behaviors and they are more directed to impulse buying. The study results also showed that brand loyalty strengthens the relationship between browsing behavior and online impulse purchase. Based on this finding, it was determined that the level of a consumer's loyalty to a specific brand increased in direct proportion with the effect of their browsing behavior on their impulse purchases on the PSCs. When consumers who are loyal to certain brands are browsing in a PSC, they wish to see the brands they are loyal to and search in framework of those brands. When people see that the PSC they are browsing offers the products of the brands they are loyal to, they have an impulsive and strong desire to buy the product with that brand. For this reason, when a person's loyalty to a specific brand is increased, his or her impulse purchase after browsing also gets stronger. Moreover, the study also proved that brand loyalty played a positive moderator role in the relationship between time pressure and online impulse buying behavior. In other words, when people's loyalty to a specific brand gets stronger, this also strengthens the effect of time pressure on the impulse purchase they will make. Consumers feel a special bond with the brands they are loyal to, and this bond strengthens their desire to own a product with that brand. People's loyalty to a brand is increased in direct proportion with the time pressure they feel in a PSC to buy that brand, and they have a stronger desire to make impulse purchase due to this time pressure. This is a unique study as there are no studies in the relevant literature of brand loyalty's moderator role in the relationship between online impulse purchase and the elements mentioned above. Moreover, the study will make a significant contribution to the literature since it shows that brand 
loyalty plays a moderator role in the relationship among perceived low price, browsing and time pressure and online impulse purchase.

\section{Managerial Implications}

The primary reason that consumers shop online is that the products offered online have more reasonable prices. The study findings showed that consumers perceive the brand products in PSCs to have lower prices than the normal sales channels, and this directs them to make impulse purchase decisions on these websites. When choosing a positioning strategy regarding their website, if the managers concerned create the perception in consumers' minds that the brand products in their website are cheaper than the ones in the competing websites, this will direct consumers to make impulse purchases on these websites. With this stretagy, the business will position itself in consumers' minds to as bringing the most potential benefit (sale).

PSCs offer the products of select brands to consumers for a limited period of time, and consumers can see when these products will be taken from their electronic carts in day, hour and minute format. The study findings indicated that this time strategy caused consumers to feel pressure regarding the buying time and make impulse purchase decisions

The study revealed that the brand's level of recognition and brand loyalty played a moderator role in the relationship between browsing, time pressure, perceived low price and online impulse buying behavior. In other words, they strengthened this relationship. Concerned managers should take this criterion into consideration when applying brand selection strategy in PSCs. When select, reliable, recognised brands with high loyalty levels are included in PSCs, this strengthens consumers' impulse purchase decisions on these websites.

\section{References}

Aaker, D. (1996) Building Strong Brands.Free Press, New York, NY.

Applebaum, W. (1951). Studying Customer Behaviour in Retail Stores. The Journal of Marketing. 16. 2, $172-$ 178.

Barbara L. Gross, B. L. (1994). Consumer Responses to Time Pressure: A Qualitative Study with Homeowners in Foreclosure. Advances in Consumer Research. 21. 120-126.

Beatty, S. E. and M. E. Ferrell. (1998). Impulse Buying: Modeling Its Precursors. Journal of Retailing. 74. 21, 169-191.

Bellenger, D. N., D. H. Robertson and E. C. Hirschman. (1978). Impulse Buying Varies by Product. Journal of Advertising Research. 18. 61, 15-18.

Biswas, A. (1992). The Moderating Role of Brand Familiarity in Reference Price Perceptions. Journal of Business Research. 15. 251-262.

Block, L. G. and V. G. Morwitz. (1999). Shopping Lists as an External Memory Aid for Grocery Shopping: Influences on List Writing and List Fulfillment. Journal of Consumer Psychology. 8. 4, 343-375.

Bloch, P. H. and M. L. Richins. (1983). Shopping Without Purchase: An Investigation of Consumer Browsing Behavior. Advances in Consumer Research. 10,389-393.

Blythe, J. (1997). The Essence of Consumer Behavior. Londan: Prentice Hall.

Buclin, R. E. and C. Sismeiro. (2003). A Model of Web Site Browsing Behavior Estimated on Clickstream Data. Journal of Marketing Research. 11. 249-267.

Byun, S. and B. Sternquistb. (2008). The Antecedents of In-Store Hoarding: Measurement and Application in the Fast Fashion Retail Environment. The International Review of Retail, Distribution and Consumer Research.18.2,133-147.

Crawford, G. and T.C. Melewar. (2003). The Importance of Impulse Purchasing Behavior in the International Airport Environment. Journal of Consumer Behavior. 3.1, 85-98. 
K. Yiğit \& Tiğglı / International Journal of Research in Business and Social Science, Vol 7 No 1, 2018 ISSN: 2147-4486

Cobb, C. J. and W. D. Hoyer. (1986). Planned Versus Impulse Purchase Behaviour. Journal of Retailing. 62. 4, 384-409.

D'Antoni, J. S. and L. S. Howard. (1973). Impulse Buying Revisited: A Behavioural Typology. Journal of Retailing. 49.1, 63-76.

Dittmar, H. and J. Drury. (2000). Self-Image - Is it in the Bag?: A Qualitative Comparison Between "Ordinary" and "Excessive" Consumers. Journal of Economic Psychology. 21.2, 109-142.

Dodds, W. B., K. B. Monroe. and D. Grewal. (1991). Effects of Price, Brand, and Store Information on Buyers' Product Evaluations. Journal of Marketing Research. 28. 3, 307-319.

Donthu, N. and A. Garcia. (1999). The Internet Shopper. Journal of Advertising Research, 39.52-58.

Gierl, H., M. Plantsch. and J. Schweidler. (2008). Scarcity Effects on Sales Volume in Retail. The International Review of Retail, Distribution and Consumer Research.18. 1, 45-61.

Hair, J. F., Black, W. C., Babin, B. J. and Anderson R. E. (1998). Multivariate Data Analysis. 7th Edition Canada: Pearson Education.

Hausman, A. (2000). A Multi-Method Investigation of Consumer Motivations in Impulse Buying Behavior. Journal of Consumer Marketing. 17. 5, 403-419

Heding, T. Knudtzen, C., F. Bjerre, M. (2009) Brand Management: Research, Theory and Practice. The Consumer Based Approach. Routledge.

Herrington, J. D. and L. M. Capella. (1995). Shopper Reactions to Perceived Time Pressure. International Journal of Retail \& Distribution Management. 23.12, 13-20.

lyer, E. S. (1989). Unplanned Purchasing: Knowledge of Shopping Environment and Time Pressure. Journal of Retailing. 65.1, 40-57.

Jarboe G. R. and C. D. McDaniel. (1987). A Profile of Browsers in Regional Shopping Malls. Journal of the Academy of Marketing Science.15.1, 46-53.

Jensen, T., J. Kees., S. Burton., and F. L. Turnipseed. (2003). Advertised Reference Prices in an Internet Environment: Effects on Consumer Price Perceptions and Channel Search Intentions. Journal of Interactive Marketing. 17. 2, 20 - 33.

Kabiraj, S. and J. Shanmugan. (2011). Development of a Conceptual Framework for Brand Loyalty: A EuroMediterranean Perspective. Journal of Brand Management.18.285 - 299.

Keller, K. L. (1993). Conceptualizing, Measuring, and Managing Customer-Based Brand Equity. Journal of Marketing. 57.1, 1-22.

Keller, K., L. (2003). Strategic Brand Management: Building, Measuring, and Managing Brand Equity. Customer Based Brand Equity. Pearon International Education

Kent, R. J. and Allen, C. J. (1994). Competitive Interference Effects in Consumer Memory for Advertising: The Role of Brand Familiarity. Journal of Marketing. 58. 97-105.

Kim, C. (1998). Brand Personality and Advertising Strategy: An Empirical Study of Mobile-Phone Services. Korean Journal of Advertising. 9. 37-52.

Kim, J. (2003). College Students' Apparel Impulse Buying Behaviors in Relation to Visual Merchandising. Published Doctoral Dissertation, University of Georgia.

Kim S. and M. S. Eastin. (2011). Hedonic Tendencies and the Online Consumer: An Investigation of the Online Shopping Process. Journal of Internet Commerce. 10. 68-90.

Krishnamurthi, L. and S. P. Raj. (1991). An Empirical Analysis of the Relationship Between Brand Loyalty and Consumer Price Elasticity. Marketing Science. 10.2, 172-183.

Kumar, R. and A. Tomkins. A Characterization of Online Search Behavior. Yahoo Research. CA, USA. 
K. Yiğit \& Tiğglı / International Journal of Research in Business and Social Science, Vol 7 No 1, 2018 ISSN: 2147-4486

Lee, D., A. K. Paswan., G. Ganesh. and M. J. Xavier. (2009). Outshopping Through the Internet: A Multicountry Investigation. Journal of Global Marketing. 22.53-66.

Lii, D. Y. and M. Lee. (2005). Consumers' Evaluations of Online Reference Price Advertisements. International Journal of Commerce \& Management. 15. 2, 101-112.

Lin. M. and B. Lee. (2012). The Influence of Website Environment on Brand Loyalty: Brand Trust and Brand Affect as Mediators. International Journal of Electronic Business Management. 10.4, 308-32.

Lin Y. and C. Chen. (2013). Passengers' Shopping Motivations and Commercial Activities at Airports - The Moderating Effects of Time Pressure and Impulse Buying Tendency. Tourism Management. 36. 426-434.

Macdonald, E. and B. Sharp. (2000). Brand Awareness Effects on Consumer Decision Making for a Common, Repeat Purchase Product: A Replication. Journal of Business Research. 48. 5-15.

Madhavaram, S. R. and D. A. Laverie. (2004). Exploring Impulse Purchasing on the Internet. Advances in Consumer Research. 31. 59-66.

McGoldrick, P.J., E. J. Betts. and K.A. Keeling. (1999). Antecedents of Spontaneous Buying Behavior During Temporary Markdowns. Advances in Consumer Research. 26. 26-33.

Nelmapius, A.H., C. Boshoff., A. P. Calitz. and B. R. Klemz. (2004). The Impact of the Information Search Variables, Time Pressure and Involvement, on Buying Behaviour in a Three-Dimensional Hypermedia Computer-Mediated Environment. South African Journal of Business Management. 36.3.

Nunnally, J. C. (1978). Psychometric Theory. 2nd Edition (2nd ed.). New York: McGraw-Hill.

Oliver, R. L. (1996). Varieties of Value in the Consumption Satisfaction Response. Advances in Consumer Research Volume. 23.143-147.

Oliver, R. L. (1999). Whence Consumer Loyalty?. Journal of Marketing. 63.33-44.

Piron, F. (1991). Defining Impulse Purchasing. Advances in Consumer Research. 18. 509-514.Rook, D. W. (1987). The Buying Impulse. Journal of Consumer Research. 14. 21, 189-199.

Priour D. L., G. Cliquet., and G. Fu. (2012). The Combined Influence of Time Pressure and Time Orientation on Consumers' Multichannel Choice: Evidence from China. The International Review of Retail, Distribution and Consumer Research. 22.5, 526-546.

Rook, D. W. (1987). The Buying Impulse. Journal of Consumer Research. 14. 21, 189-199.

Rook, D. W. and R. J. Fisher. (1995). Normative Influences on Impulsive Buying Behavior. Journal of Consumer Research. 22. 31, 305-313.

Spears, N. (2013). Time Pressure and Information in Sales Promotion Strategy: Conceptual Framework and Content Analysis. Journal of Advertising. 30. 1, 67-76.

Stern, H. (1962). The Significance of Impulse Buying Today. Journal of Marketing. 26..2, 59-62.

Swain, S. D., R. Hanna. and L. J. Abendroth. (2006). How Time Restrictions Work: The Roles of Urgency, Anticipated Regret, and Deal Evaluations. Advances in Consumer Research. 33. 523-525.

Tabachnick and Fidell (2007) Barbara G. Tabachnick, B. G. and Fidell, L. S. (2007). Using Multivariate Statistics. 5th Edition Canada: Pearson Education.

Taylor, S. A., K. Geluch. and S. Goodwin. (2004). The Importance of Brand Equity to Customer Loyalty. The Journal of Product and Brand Management. 13. 4/5, 217-227.

Tinne, W. S. (2010). Impulse Purchasing: A Literature Overview. ASA University Review. 4. 2, 65-73.

Zhou, L. and A. Wong. (2003). Consumer Impulse Buying and In-Store Stimuli in Chinese Supermarkets. Journal of International Consumer Marketing. 16.2, 37-53. 